\title{
REVIEW
}

UDC 579.841.11.22

doi: https://doi.org/10.15407/ubj91.01.005

\section{Pantoea agglomerans LIPOPOLYSACCHARIDES: STRUCTURE, FUNCTIONAL AND BIOLOGICAL ACTIVITY}

\author{
L. D. VARBANETS $\bowtie$, T. V. BULYHINA, L. A. PASICHNYK, N. V. ZHYTKEVICH \\ Zabolotny Institute of Microbiology and Virology, \\ National Academy of Sciences of Ukraine, Kyiv; \\ 凶e-mail:varbanets_imv@ukr.net
}

Received: 02 September 2018; Accepted: 13 December 2018

This review analyzed literature data, as well as our own research on lipopolysaccharides (LPS) of gram-negative bacteria, focusing mainly on Pantoea agglomerans, a member of the Enterobacteriaceae family. The unique structures of $O$-specific polysaccharide chains of LPS from Pantoea agglomerans represented by both linear and branched tetra- and pentasaccharide repeating units were described for the first time. The heterogeneity of the LPS molecule itself and the presence of several LPS in the bacterial cell, which differ in the structure of lipids A, O-specific polysaccharide chains, serological activity, as well as endotoxic properties, such as toxicity and pyrogenicity, were shown. Such heterogeneity represents one of the mechanisms of LPS multifunctionality. Based on the antigenicity of LPS, serotyping of P. agglomerans strains and their assignment to 10 serogroups were carried out for the first time. The high immunomodulatory activity of $P$. agglomerans LPS suggests the possibility to use their oligosaccharide fragments in the development of conjugated vaccines against diseases caused by gram-negative bacteria.

Keywords: Pantoea agglomerans, O-specific polysaccharide, lipid A, serological activity, TLR 4 receptor, biological activity.

$\mathrm{T}$ he representatives of the Enterobacteriaceae family, an essential part of the biosphere and widely distributed in the environment, were among the first microorganisms that became a subject of research. Their activity affects the various spheres of human life significantly. Although Enterobacteriaceae family is the most studied (phenotypically and genotypically) family, its classification is still changing and improving. It happens due to the considerable biological diversity of enterobacteria that complicates the classification of the family members. The greatest difficulties arise when identifying newly discovered and poorly studied species.

However, in the recent years, the improvement to traditional and the development of new methods in systematic have resulted in the identification of 48 Enterobacteriaceae genera, among them is Pan- toea, which is related (for 25\%) to the typical genus Escherichia. This level of relationship is fairly high compared to other genera, such as Budvicia (1\%), Pragia (5\%) and Rahnella (15\%) [1].

$P$. agglomerans is considered one of the most abundant microorganisms, at least in areas inhabited by humans. The ability of these bacteria to compete and survive in various environments makes them especially useful for biocontrol, bioremediation, and biodegradation. $P$. agglomerans representatives have been classed over the years with various bacteria genera and types: Enterobacter agglomerans, Erwinia herbicola, Erwinia milletiae. Only in 1989, the new genus Pantoea, which includes the P. agglomerans species having a diverse range of properties, was applied to the Enterobacteriaceae family [2]. Initially, representatives of this species were found

(C) 2019 Varbanets L. D. et al. This is an open-access article distributed under the terms of the Creative Commons Attribution License, which permits unrestricted use, distribution, and reproduction in any medium, provided the original author and source are credited. 
in plants [1, 3], later they have been determined in water, soil, dust, air, plant and animal products, in the body of arthropods and other animals, and sometimes in humans (in wounds, blood, internal organs) $[1,4,5]$. This bacterium in humans can have an ambiguous effect, both pathogenic and beneficial. On the one hand, it can cause diseases in people who inhale organic dust [6], on the other hand, it can stimulate the production of substances that are effective in the treatment of cancer and other diseases [7].

Recently, Nicoletti et al. suggested that $P$. agglomerans along with other 8 bacteria species (Aeromonas hydrophila, Brevundimonas vesicularis, Chromobacterium violaceum, Citrobacter youngae, Empedobacter brevis, Pseudomonas putida, Pseudomonas stutzeri and Streptococcus mitis) found in the Comano spring water can contribute to its regenerative and wound-healing properties [8].

The publications of the recent years have considered the promising potential of $P$. agglomerans strains in fighting malaria. Bacteria of this species were detected in the midgut of Anopheles mosquitoes infected with Plasmodium [9-11]. About 300500 million cases of malaria resulting in 1.2 million deaths are registered annually [11]. The symbiotic existence of Pantoea with malaria mosquitoes enables the development of a strategy called paratransgenesis, in which, bacteria express antiplasmodic effector proteins in the mosquito's midgut. Researchers demonstrated that the introduction of $P$. agglomerans strains inhibited (98\%) the development of the human malaria parasite Plasmodium falciparum and the rodent Plasmodium berghei [11]. These results provide new approaches to combating this lethal disease.

Lipopolysaccharides (LPS), the main components of the outer membrane of gram-negative bacteria, play an important role in host-pathogen interactions in animals and plants [12]. The outer membrane of gram-negative bacteria has a unique asymmetric phospholipid bilayer structure: its inner leaflet consists of glycerophospholipids, whereas the outer one is rich in lipopolysaccharide covering about $75 \%$ of the cell surface. Integral membrane proteins, porins, are also embedded in the outer membrane, and together with LPS provide a barrier of permeability for different types of molecules, such as detergents, antibiotics, metals. The barrier properties of the outer membrane are attributed to low fluidity and a highly ordered structure of the LPS monolayer [1, 13, 14].

Although lipopolysaccharides (endotoxins) were discovered more than 100 years ago, these complex macromolecules still draw attention not only of biochemists, but also chemists, physicists, molecular biologists who study their structure and biological activity.

One of the mechanisms that determine the lipopolysaccharide polyfunctionality could be the heterogeneity of its molecule, consisting of carbohydrate and lipid parts, and the presence in the bacterial cell of several lipopolysaccharides, which differ in composition, structure and functions. Studies of lipopolysaccharides facilitate the solving such fundamental problems as: the bacteria classification, determining the correlation between the structure and function of lipopolysaccharides, the mechanisms of the immune response, the development of serological classification schemes, based on structural variations in LPS O-specific chains. Thus, the structural features of LPS have been successfully used in chemotaxonomy of some gram-negative bacteria such as Escherichia coli, Salmonella typhimurium, Shigella flexneri, Pseudomonas aeruginosa, Pseudomonas syringae. However, in P. agglomerans taxonomy, there are still many unsolved problems. At the same time, the published data on isolation and characteristics of the lipopolysaccharides from $P$. agglomerans representatives remain extremely limited. Since $P$. agglomerans constantly enter into the gastrointestinal tract of humans and farm animals with vegetables and other plant foods, study the functional and biological properties of LPS, isolated from representatives of this species, in particular, toxicity, pyrogenicity, antigenic properties, are vitally important. These properties are known to depend, first of all, on the composition and structure of LPS molecules [15, 16].

Structure and peculiarity of the structural arrangement of $\boldsymbol{P}$. agglomerans LPS. The structure of LPS from P. agglomerans, like the structure of LPS from other gram-negative bacteria, include three components, namely O-specific polysaccharide (known as O-antigen) (OPS), core oligosaccharide (COS) and lipid A (Fig. 1).

The LPS molecule is anchored into the outer membrane of gram-negative bacteria via hydrophobic interaction between lipid A fatty acids and phospholipids.

The complete LPS molecule, which comprises all three components, is called the smooth (S)-form LPS. The LPS, which lacks the O-specific polysaccharide and/or part of the core oligosaccharide, is called the rough (R)-form LPS (Fig. 2). 


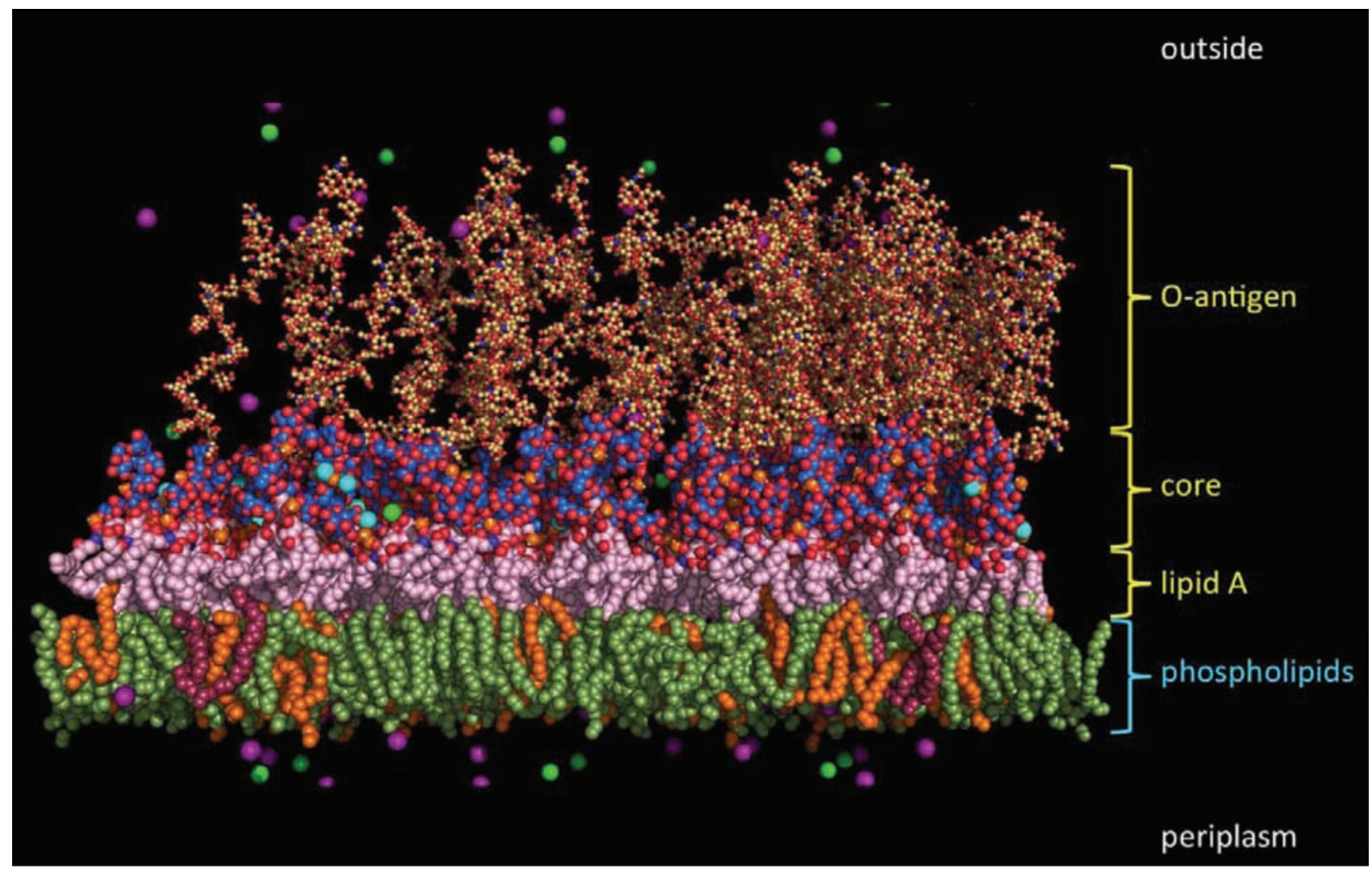

Fig. 1. Typical E. coli LPS (O-antigen polysaccharide, core oligosaccharide, and lipid A) arrangement in outer membrane [15]

The absence of OPS in LPS of some bacteria occurs as a result of either the absence or inactivation of the $\mathrm{O}$-antigen gene cluster. When bacteria are not able to polymerize the O-chain, they synthesize LPS consisting of the only one O-unit attached to COS. Several different forms of LPS can coexist in the same strain. The OPS chain varies considerably in length: from one to more than 50 O-units. The distribution of the chain length is modal (except for bacteria that have S-LPS) and specific for different bacteria strains.

The lipid A structure is the most conservative component of the LPS molecule, whereas the O-polysaccharide chains are the most variable one. Each component performs specific functions: OPS are responsible for the serological activity of bacterial cells and serve as receptors for bacteriophages and bacteriocins; the core oligosaccharide

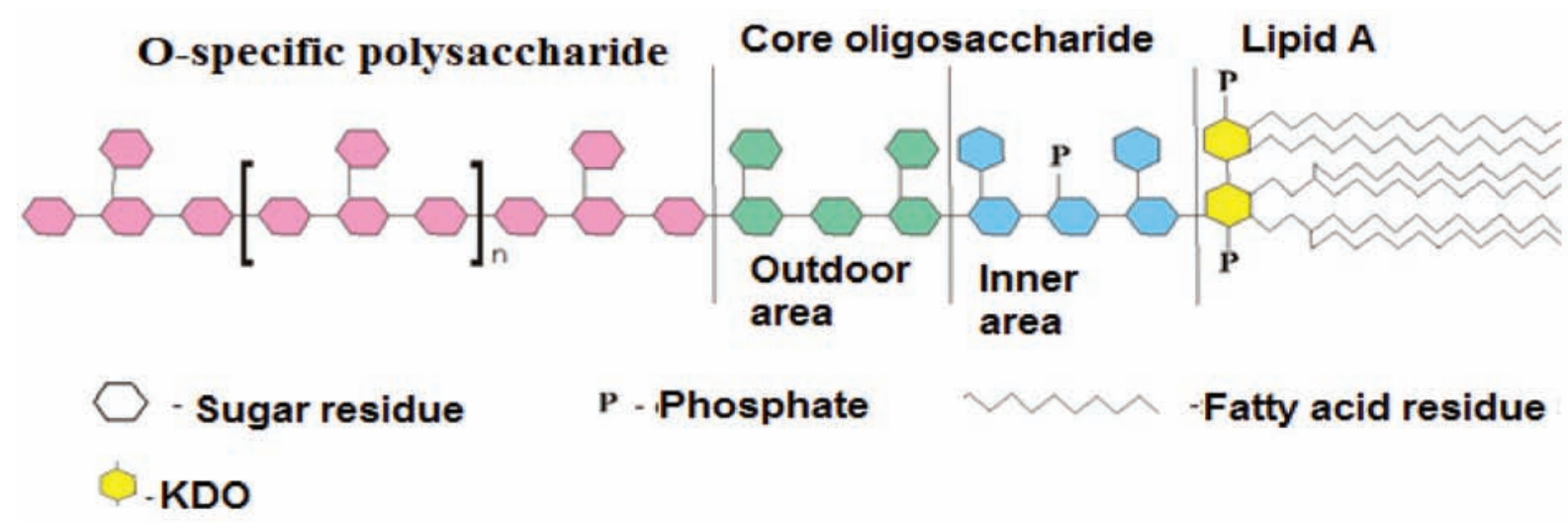

Fig. 2. The common structure of the LPS molecule [26] 
is involved in maintaining the integrity of the outer membrane, and lipid A is the LPS anchor to embed in the bacterial outer membrane via electrostatic and hydrophobic interactions with phospholipids and is responsible for the endotoxic properties of gramnegative bacteria [16].

The carbohydrate part (O-specific polysaccharide and core oligosaccharide) is attached to lipid A by a glycosidic bond through the residue of 2-keto3-deoxyoctonic acid (KDO) (Fig. 3) [16, 17]. This labile acid bond can be selectively cleaved under mild acid hydrolysis conditions into carbohydrate and lipid parts.

Lipid A consists of two $\beta(1 \rightarrow 6)$-linked Dglucosamine residues, which carry fatty acids and phosphate groups attached via amide and ester bonds at the C-1 and C-4' positions [18-20] (Fig. 4). Fatty acids can be saturated (in rare cases, unsatu- rated), as well as hydroxylated. 3-OH-hydroxy acids are differentiating for certain types of bacteria. Therefore, the composition of fatty acids is used as one of the chemotaxonomic criteria in the bacterial systematics.

In lipid A of the studied P. agglomerans [21] strains, the following fatty acids were found to predominate: 3-OH-C14:0 (31.7-60.6\%), C14:0 (12.930.8\%), C12:0 (8.2-30.4\%), C16:1 (4.2-27.4\%), C16:0 (3.3-17.3\%). LPS of the two studied strains also contained 2-OH-C14:0 acid. Only one strain lacked C14:0 acid and three strains contained C18:0 acids. In some cases ( 3 strains), insignificant amounts of C18:0, as well as cis- and trans-C18:1 acids were detected; aic C15:0 acid was found in only one strain. The fatty acid composition of lipid A from studied early $P$. agglomerans strain was shown to distinguish by the absence of C16:1, C18:1 and C18:0 acids a

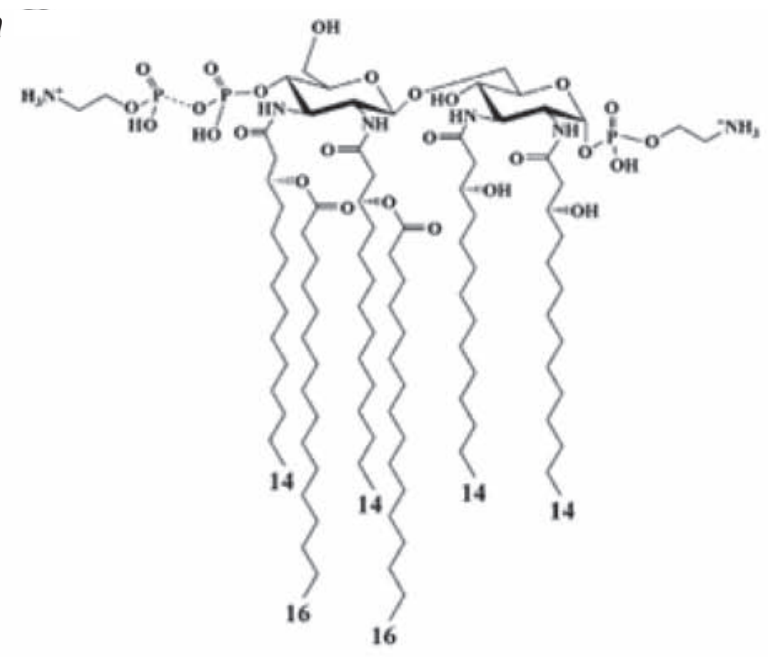

C

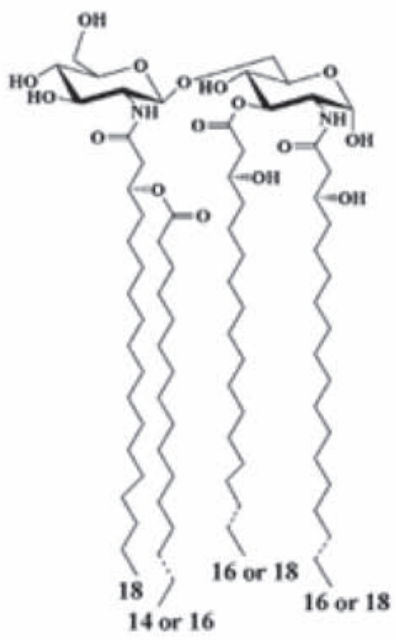

b

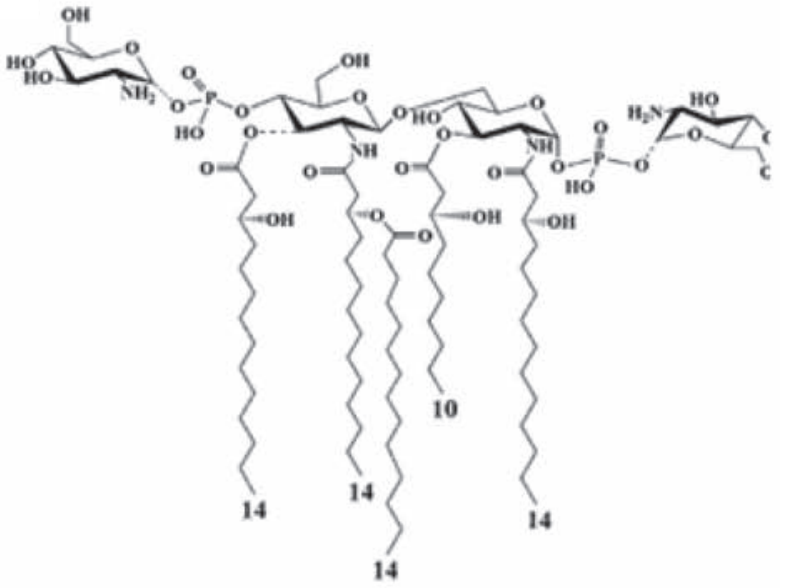

d

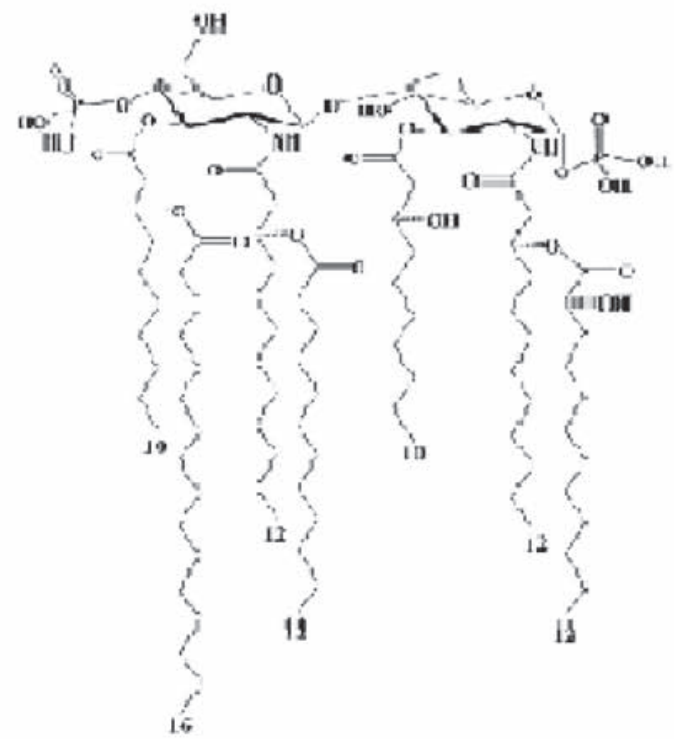

Fig. 3. Structures of lipid A variants: a - hexaacyl, b-pentaacyl, c-tetraacyl, d-heptaacyl [26] 
[22]. The analysis of the published data indicates a variety of lipid A fatty acid compositions of LPS in different $P$. agglomerans strains.

The presence of only one 3-hydroxytetradecanoic acid, which acylates amino and hydroxy groups of glucosamine residues, is a distinctive feature of lipids A of the Enterobacteriaceae family members, whereas, for the majority of the studied gram-negative bacteria strains, the fatty acid composition is a species-specific characteristic [23].

Thus, despite a conservative structure, lipid A is characterized by considerable microheterogeneity, which depends on various factors, including bacterial adaptation to changing environmental conditions, incomplete biosynthesis, chemical modifications emerged in isolated lipids. Lipids A vary in the amount of fatty acids, their distribution along the disaccharide molecule of glucosamine, chain length and stereochemistry. The presence of charged groups in lipid A is essential for a variety of LPS biological activities, including the resistance of bacteria to antibiotics [24]. Thus, phosphate groups may be substituted with polar or other groups. Most common polar substituents of phosphate groups, which are usually present in non-stoichiometric amounts, are: secondary phosphate (lead to the formation of a diphosphate group), hydrogen, heptose, galacturonic acid, phosphoethanolamine, and 4-amino-4-deoxy-Larabinose $[12,25]$. These substituents affect the biological properties of not only LPS but also the entire bacterial cell. Thus, it was established [26, 27] that the substituents at 4'-phosphate of glucosamine II result in the bacterial resistance to some polycationic antibiotics, in particular, polymyxin B. In case, when the $\mathrm{OH}$ group at 4'-phosphate of glucosamine is not substituted, polymyxin $\mathrm{B}$ is attached to the $\mathrm{OH}$ group, and such bacteria are polymyxin sensitive. When there is substituent, such as 4-amino-4-deoxyL-arabinose, at the $\mathrm{OH}$ group, polymyxin is not able to bind, and such bacteria become polymyxin-resistant. Since only one $P$. agglomerans strain among 14 studied showed resistance to polymyxin B [36], it can be assumed that lipid A of LPS isolated from this strain contains substituent 4-amino-4-deoxy-Larabinose. LPS of the rest 13 strains presumably do not contain a substituent at $\mathrm{C}^{\prime}$ ' of glucosamine II. This assumption proved to be correct when the lipid A structures of three $P$. agglomerans strains $8674^{\mathrm{T}}$, 7604, and 7969 were analyzed by GC-MS and highresolution ESI-MS [28, 29].

Usually, lipid A has a hexaacyl structure, in which 6 acyl chains of different lengths are esterified with glucosamine disaccharide (Fig. 3). However, certain bacteria can synthesize under-acylated lipid A, for example, tetra- or pentaacyl forms [30, 31] or even over-acylated, such as the heptaacyl lipid A [31, 32].

Tsukioka et al. showed that lipopolysaccharide of $P$. agglomerans carries at least two types of lipids A with different levels of acylation [22]. One was the same as Escherichia coli 4'-monophosphorylhexaacyl-lipid A, and the other was similar to Salmonella enterica 4'-monophosphorylheptaacyl-lipid A. These LPS also differed in molecular weight: $5 \mathrm{kDa}$ and 30-60 kDa, respectively.

Similar results were obtained by other researchers who detected two lipid A types in the LPS from $P$. agglomerans [33, 34]. They are characterized by low molecular weight and differ from the previously described structures only by the presence of an additional oxygen atom at the acyloxyacyl ester-linked side-chain of the distal portion of the molecule.

GC-MS and high-resolution ESI-MS analysis of lipids A of P. agglomerans 7604, 7969 and 8674 strains revealed their high heterogeneity $[28,29]$. Lipid A from $P$. agglomerans $8674^{\mathrm{T}}$ was represented by hexa-, penta-and tetraacyl species [29]. The hexaacyl species included four 3-OH-C14:0 residues, one C14:0 residue and one C12:0 residue; the pentaacyl species was characterized by the absence of one C14:0 residue and the tetraacyl species did not contain two fatty acid residues, namely 3-OH -C14:0 and C14:0. In addition, peaks corresponding to hexa-, penta- and tetraacyl species, in which C14:0 or C12:0 residues were substituted with C16:1 or C18:1 residue, respectively, were observed. Moreover, in the hexaacyl species, additional peaks appeared, probably due to the substitution of C14:0 for C16:0 or 2-OHC14:0, as well as corresponding monophosphorylated derivatives, were registered.

Analysis of the mass spectra of the lipid A of LPS from $P$. agglomerans 7969 showed two main peaks for diphosphorylated disaccharides, which correspond to hexa- and tetraacyl species, with the same residues as $P$. agglomerans $8674^{\mathrm{T}}$ strain. These data are consistent with previously published data on the structure of lipid A of P. agglomerans [22]. There are also peaks corresponding to two more hexaacylated species, in which C14:0 acids are likely to be replaced by C16:0 or 2-OH-C14:0; and peaks corresponding to monophosphorylated derivatives.

On the spectrum of $P$. agglomerans strain 7604, two species of lipid A were observed: pentaacyl with 
four 3-OH-C14:0 residues and one $\mathrm{C} 12: 0$ residue and tetraacyl - without one 3-OH-C14:0 residue [29]. Both derivatives demonstrated peaks appeared as a result of substitution C12:0 with C18:1, and peaks corresponding to monophosphorylated derivatives.

It can be concluded based on the obtained data on LPS lipid A structures of three $P$. agglomerans strains that they are heterogeneous, characterized by different degrees of acylation and do not contain any monosaccharides as substitutes at $\mathrm{C}^{\prime}$ ' position. These findings were confirmed by the results of the studying the sensitivity of these strains to polymyxin $\mathrm{B}$ [35].

OPS structure. It is known that OPS structure is characterized by variability [26]. To determine OPS structure, researchers use the traditional methods, such as gas-liquid chromatography, periodate oxidation, methylation, determination of the absolute configuration of monosaccharides along with the most advanced ones, such as chromatography-mass spectrometry, NMR spectrometry, computer analysis [36]. The use of a combination of modern biochemical and biophysical methods enabled to characterize the unique structures of the OPS in many bacteria species [26, 37].

Typical components of OPS are monosaccharides, which occur in nature. Most of them exist in the form of pyranose, but some can be represented by furanoses (arabinose, ribose, xylose) or by both forms (galactose, fucose, paratose). In some OPS, ribose occurs in the form of pyranose, and N-acetylgalactosamine - in the form of furanose. An OPS usually contains $\mathrm{N}$-acetyl and $\mathrm{O}$-acetyl groups, less often - methyl group bound to hydroxyl or amino groups. In various OPS, the hexuronic acid may occur as an amide with an amino component, such as 2-amino-2-deoxyglycerol (GroN) or amino acid (L-lysine and its Ne-(1-carboxyethyl) derivative). Phosphate was found only in the form of a diester, including cyclic phosphate [26].

The O-antigen structures are mostly established for bacteria from the Enterobacteriaceae family. Thus, at present, the full O-antigen structures have been identified for more than 180 strains of $E$. coli, which is a type species of the Enterobacteriaceae family. They contain linear or branched tri-, tetra-, penta- and hexasaccharides; less commonly disaccharides or homopolysaccharides [26].

Data on the OPS structures of $P$. agglomerans representatives are limited. Thus, it was shown [34] that the OPS from $P$. agglomerans contain a branched heteropolymer with repeating pentasaccharide units, containing rhamnose, glucose, NAcglucosamine and NAc-fucosamine residues (I).

A neutral OPS isolated from $P$. agglomerans strain FL1 was found to have a completely different structure. Thus, it is constituted by a homopolymer arranged as linear tetrasaccharide repeating units consisting of D-rhamnose residues [38]:

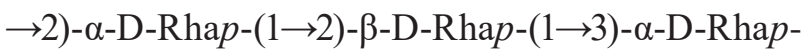
$(1 \rightarrow 2)-\alpha-D-R h a p-(1 \rightarrow$

Hashimoto et al. showed that the structure of OPS of LPS from P. agglomerans IG1 (IP-PA1) is composed of linear tetrasaccharide repeating units consisting of glucose and rhamnose residues, in which $40 \%$ of one of the rhamnose residues is substituted with glucose [39]:

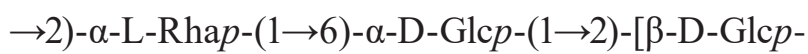
$(1 \rightarrow 3)] 0.4-\alpha$-L-Rhap $-(1 \rightarrow 2)-\alpha-L-R h a p-(1 \rightarrow$

This means that if OPS consists, for example, of 10 repeating units, only in four of them rhamnose is replaced by glucose, and the rest are unsubstituted. This leads to one of the possible heterogeneities of the LPS molecule that plays a significant role in its biological activity.

A similar structure, where rhamnose residues were substituted with glucose, was identified in the OPS from Shigella flexneri serotype X [40]:

$\rightarrow 3)-\beta$-D-Glc $p$ NAc- $(1 \rightarrow 2)-[\beta-D-G l c p-(1 \rightarrow 3)]-\alpha$-LRha $p-(1 \rightarrow$

The structures of the OPS from P. agglomerans $8674^{\mathrm{T}}$ and $P$. agglomerans 7604 were shown to have similar features and constituted by branched pentasaccharides containing 3 rhamnose residues and 2 glucose residues, one of which was in the lateral position (II). The only difference was that in $8674^{\mathrm{T}}$

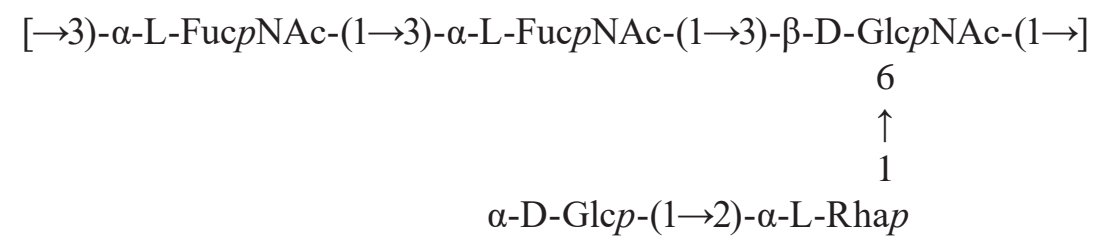

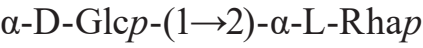


P. agglomerans $8674^{\mathrm{T}}$

$$
\begin{aligned}
& \rightarrow 2)-\alpha \text {-L-Rhap- }(1 \rightarrow 2)-\alpha \text {-L-Rhap- }(1 \rightarrow 2)-\alpha \text {-L-Rhap }-(1 \rightarrow 2)-\alpha \text { - D-Glcp- }(1 \rightarrow \\
& \beta \text {-D-Glcp- }(1 \rightarrow 3)\rfloor \\
& \text { P. agglomerans } 7604 \\
& \begin{array}{l}
\rightarrow 2)-\alpha-\mathrm{L}-\mathrm{Rhap}-(1 \rightarrow 2)-\alpha-\mathrm{L}-\mathrm{Rhap}-(1 \rightarrow 2)-\alpha \text {-L-Rhap }-(1 \rightarrow 2)-\alpha-\mathrm{D}-\mathrm{Glc} p-(1 \rightarrow \\
\alpha \text {-D-Glcp- }(1 \rightarrow 3)
\end{array}
\end{aligned}
$$$$
\rightarrow 3)-\alpha-L-R h a p-(1 \rightarrow 6)-\alpha-D-M a n p-(1 \rightarrow 3)-\alpha-D-F u c p-(1 \rightarrow 3)-\beta-D-G l c p N A c-(1 \rightarrow
$$$$
\text { Gro-1-P-(O } \rightarrow 6) \text { 」 }
$$

strain the glucose residues in the lateral position had $\beta$-configuration, and in 7604 strain - $\alpha$-configuration [29].

It was reported that the main chain of neutral OPS isolated from Serratia marcescens 111 LPS (O29) has the same structural features; however, the lateral substituents were not identified in its structure [41].

The structure of OPS from $P$. agglomerans 7969 [28] differ greatly from the structures described above and is constituted by a linear tetrasaccharide consisting of rhamnose, mannose, fucose, and Nacetylglucosamine residues (III).

Its structure appeared to be heterogeneous due to non-stoichiometric ( $25 \%$ ) substitution at position 6 of $\mathrm{N}$-acetylglucosamine residue with glycerol 1-phosphate. Earlier, this type of heterogeneity was identified in the OPS from Proteus vulgaris TG103 [42]. There has been no reported data on such structure so far. However, the rhamnose and glucosamine disaccharide fragments are quite common in gram-negative bacteria, for example, Agrobacterium tumefaciens F1, Serratia marcescens $\mathrm{O} 17$ and O19, Klebsiella pneumonia O12. In OPS from Stenotrophomonas maltophilia O6, this disaccharide is xylosylated at position 4 GlcNAc [43].

LPS functions. The structural components of the LPS molecule differ not only in structure but also in functions and biological activity. Thus, lipid $\mathrm{A}$ is responsible for the endotoxic activity of the molecule, while the O-specific polysaccharide is associated with the $\mathrm{O}$-serological specificity of the bacterial cell. Therefore, subtle variations in LPS structures are the basis for the development of intraspecies serological classification schemes for gram-negative bacteria. The first serological classification scheme based on the structures of O-speci- fic polysaccharides (10 structures) was proposed by Kauffmann and White for the Salmonella genus [44]. The authors showed that the serotypes of Salmonella genus members are determined by the presence of substituents at mannose or galactose. Thus, 3,6-dideoxy-hexoses, such as paratose ( $S$. paratyphi), abequose (S. abortus equi, $S$. typhimurium), tyvelose (S. typhi, S. trasbourg) can be bound to the mannose as the side chain via the $\alpha-1,3$ bond. Glucose attached to galactose by $\alpha-1,4$ or $\alpha-1,6$ bonds may be present as another side chain. In polysaccharides of group B Salmonella, abequose is often acetylated at C-2. Thus, in S. typhimurium, most abequose residues were found to be present in the form of $\mathrm{O}$ acetyl derivatives.

Significant progress made in the last decades in studying OPS structures has allowed determining 46 serogroups for Salmonella enterica, 46 - for Shigella representatives, 76 - for Proteus, 61 - for Providencia, 39 - Hafnia. The most large-scale study has been carried out on E. coli, in which more than 180 serogroups have been identified [45].

A study of the serological activity of LPS from 14 strains of $P$. agglomerans by Ouchterlony double immunodiffusion between antisera to the studied strains and LPS isolated from the homologous strains demonstrated that LPS exhibit antigen activity [21]. However, it was found in serological cross-reaction tests between antisera and LPS from different strains that only some of them exert cross-reactivity. These findings enabled to divide, for the first time, the 14 studied $P$. agglomerans strains into 10 serogroups based on the LPS O-antigenic properties. This is the only study on the serological identification of $P$. agglomerans strains known currently [21].

LPS biological activity. The complex structure of the LPS molecule and its heterogeneity, as well as 
the presence of several LPS differing in molecular mass and structure within the same strain of bacteria, determine LPS polyfunctionality. On the one hand, LPS perform a biological protective function, are involved in cell adhesion, exhibit mitogenic activity and antitumor effect, and can serve as markers for bacterial strain identification. LPS can activate B- and T-lymphocytes, granulocytes and mononuclear cells and thus, are considered as potential immunomodulators. LPS, having antigenic activity, serve as biological recognition components, carriers of specific information determining the relationship between bacteria and macro-/microorganisms. On the other hand, as bacterial endotoxins, LPS in higher animal and human induce a wide range of pathophysiological reactions that can lead to septic shock, and be fatal in some cases. Owing to these properties, LPS contribute to the pathogenic potential of gram-negative bacteria, and thus, to the outbreak of severe infectious diseases. The pathogenesis of sepsis includes the following phases: neutrophil, monocyte and macrophage inflammatory reactions, intravascular coagulopathy, endothelial cell injury, and hypotension. Thus, LPS has a pleiotropic effect on tissues and organs that can lead to death [46]. Recently, researchers have found specific LPS receptors on the immune cell surface and blood proteins, which can recognize the minor differences in the LPS structure and make an organism to respond. Since the biological activities of LPS correlate with their structures, the latest findings on the LPS structures have enabled to investigate the mechanism of the LPS biological activity at the molecular and cellular level. Understanding these mechanisms is essential for solving some fundamental problems of immunogenesis and cell reception. The crucial point in the investigation was the discovery by Bruce Beutler in 1998 of the LPS receptor, Toll-like receptor, when he studied the effect of LPS on mice [47]. This receptor is similar to the protein coded by the Toll gene identified in Drosophila in 1995. LPS was shown to trigger an immune response via interaction with Toll-like receptor 4 (TLR4), which is a key receptor of innate immunity.

Identification of the LPS receptor was essential for understanding the mechanisms of innate immunity. In 2011, Bruce Beutler, Jules Hoffmann and Ralph Steinman received Nobel Prize in Physiology or Medicine for their discoveries of one of the molecular mechanisms for activation of innate immunity [48]. Toll-like receptor activation occurs when it binds to ligands, which can be certain moieties of bacteria, fungi or viruses. Fig. 4 presents the scheme, in which LPS of gram-negative bacteria is a ligand, and Toll-like receptor 4 (TLR4), which is a surface protein remotely related to the IL-1 receptor [48]. For the recognition of lipopolysaccharide, TLR4 require the presence of transport proteins such as lipopolysaccharide binding protein (LBP), soluble and membrane-bound CD14 proteins [49]. Genetic and biochemical analyses revealed that for the subsequent recognition of the LPS/CD14 complex by the TLR4 receptor, other proteins are also needed, in particular, TLR4-associated co-receptor MD-2 [50]. This protein belongs to the family of lipid-binding proteins [51, 52], which characterized by the $\beta$-sandwich structure. In the signaling pathway, TLR4 recognizes hexaacyl diphosphorylated domain of lipid A. The binding to LPS is achieved by intercalation of lipid A acyl chains into hydrophobic region of $\beta$-sandwich $[53,54]$. This model was confirmed by structure analysis of MD-2 associated with lipid IVa, as well as a TLR4/MD-2 heterodimer in complex with the structurally related to lipid IVa synthetic compound E5564 [55, 56]. Activated by this complex macrophages or mononuclear phagocytes trigger the biosynthesis of various inflammatory mediators, such as TNF, IL-1, IL-6, IL-8, as well as adhesive molecules necessary for the adaptive immune response $[57,58]$.

A leading role in the LPS induction of most biological effects is performed by lipid A [58], because after removal of the core oligosaccharide and the O-specific polysaccharide from LPS, TLR4 is still able to recognize it. Tetraacyl and hexaacyl LPS from $E$. coli are the most studied. The cumulative effect of acyl groups in lipid A has been revealed: the more acyl residues and the longer the chains of acyl groups in lipid A structure, the more proinflammatory cytokines macrophages produce. Thus, a direct link between the biological activity of LPS and the chemical structure of lipid A was demonstrated.

The first data on the biological activity of LPS extracted from 10 strains of $P$. agglomerans isolated from dust, air, human and animal sources were presented by Dutkiewicz in 1976 [59]. Thomas in 1956 showed that $P$. agglomerans LPS mixed with adrenaline caused dermal hemorrhagic lesions in rabbits and death of the 10-day-old chicken embryos [60].

In further research, a significant increase in the number of polymorphonuclear leukocytes and alveolar macrophages was detected $24 \mathrm{~h}$ after guinea 


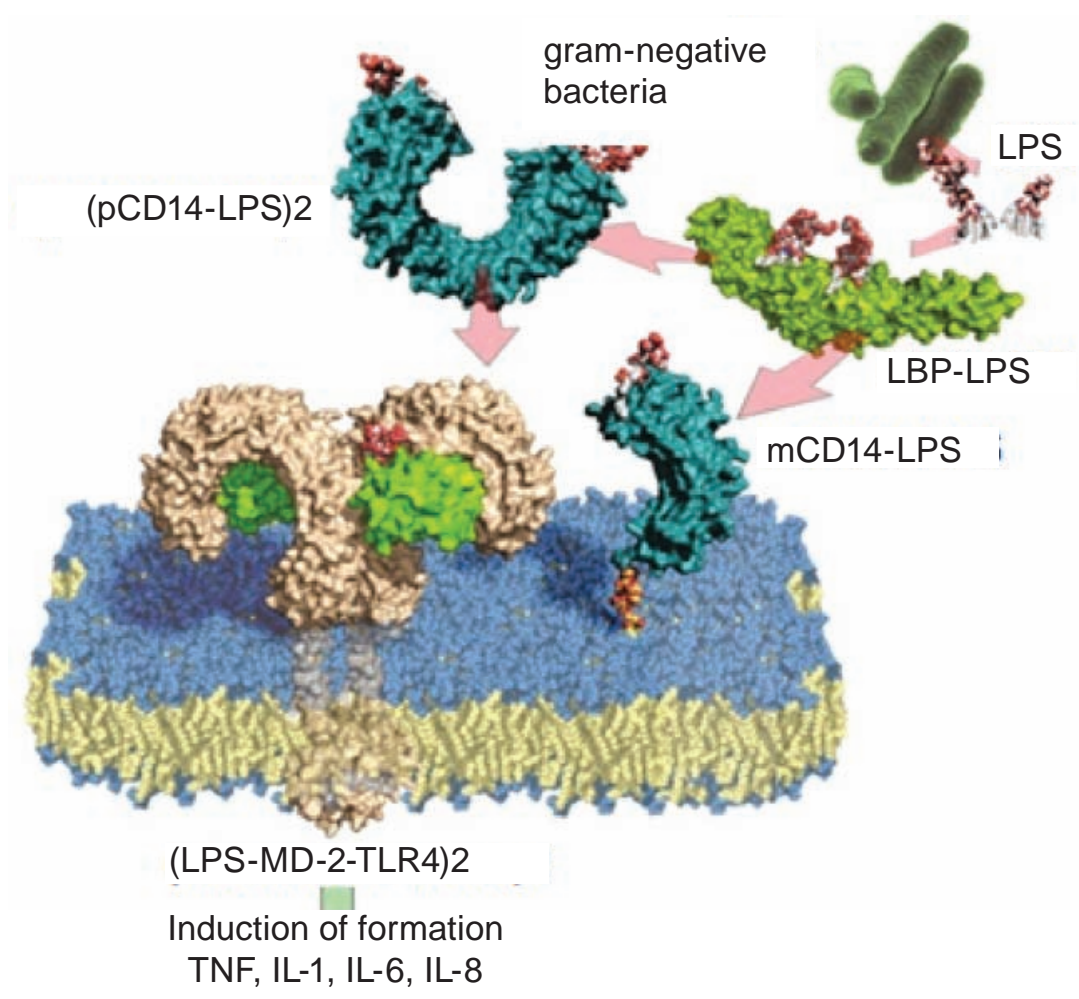

Fig. 4. TLR4 receptor recognition of lipid A [61]

pigs inhaled live cell suspensions or LPS from $P$. agglomerans isolated from cotton [61-63]. These LPS also caused the death of mice and were pyrogenic for rabbits [64].

In 1991, the compound, which activated macrophages after oral or subcutaneous administration, was discovered in an aqueous extract of wheat flour [56]. The active compound was identified as LPS isolated from P. agglomerans cells that were in symbiosis with wheat. The authors called this lipopolysaccharide as IP-PA1 (immunopotential from P. agglomerans, a former name: LPSp) and showed its effectiveness in various areas, such as healthy diet (to prevent or reduce metabolic syndrome), skin care products (to maintain healthy skin), as well as active ingredients in animal feed and aquaculture. Later, IP-PA1 administered orally or subcutaneously was shown to activate peritoneal macrophages and increase the activity of phagocytes through TLR4 signaling pathway $[55,56]$.

Iwamoto et al. demonstrated that intravenous co-administration of LPS from $P$. agglomerans with cyclophosphamide resulted in complete regression of mouse hepatoma MH134 [65]. In mice treated by this method, the researchers observed necrosis and inflammatory cell infiltrates (CD4+ and CD8+ T-lymphocytes, macrophages, neutrophils) in tu- mors and the related increase in serum cytokines (TNF- $\alpha$, IL-1 $\alpha$, IL-6, G-CSF (granulocyte colonies stimulating factor)). It was concluded that treatment with LPS was effective mainly due to increased Tcell mediated antitumor immunity developed by the synthesis of TNF- $\alpha$ and other cytokines. These results were confirmed by Inagawa et al. $[64,66]$ who showed the complete regression of syndromal mouse tumors, Meth A fibrosarcoma, MH134 hepatoma, and Lewis carcinoma after combined treatment with intravenous administration of LPS with cyclophosphamide. The researchers indicated that the induction of TNF- $\alpha$ plays an important role in successful therapy and that subcutaneous drug administration was low toxic (by 230-380 times less) compared to intravenous administration.

Japanese researchers described this new medication, containing low molecular weight (5 kDa) LPS and with no side effect, as immunostimulator $P$. $a g$ glomerans 1 and suggested it for the treatment of a range of diseases including malignant tumors by oral or intravenous administration [47].

In addition, oral administration of IP-PA1 was shown to prevent diabetes, as well as infectious diseases caused by bacteria and viruses [56]. However, it is still not clear whether IP-PA1 administered orally, and absorbed in the intestine, enters into tis- 
sue macrophages. From drug delivery point of view, it is important to identify the IP-PA1-binding cells after IP-PA1 oral administration.

Dutkiewicz et al. reported that significant amounts of $P$. agglomerans were found in grain and flour dust in the form of globular nanoparticles measuring 10-50 $\mathrm{nm}$, which can be described as "endotoxin super macromolecules" [67]. Their concentration in dust was found to range from $10^{4}$ to $10^{5} \mathrm{CFU} / \mathrm{g}$ and formed $73.2-96 \%$ of the total gramnegative bacteria in the air [67]. Therefore, researchers consider $P$. agglomerans as major causative agents of toxic pneumonia in agricultural workers. Indeed, $P$. agglomerans endotoxins were shown to cause inflammatory and fibrotic changes in lungs, to stimulate alveolar macrophages, to produce anion superoxide, interleukin-1 and chemotactic factors for other macrophages and neutrophils, and to increase the concentrations of pulmonary toll-like receptors and chemokines [67]. Researchers believe that LPS and proteins from $P$. agglomerans should be considered as major causative agents of occupational diseases, such as allergic dermatitis in farmers, and also allergic pulmonary disorders in cattle not only in the cotton industry but also for the grain industry and agriculture.

In 2016, researchers obtained impressive results demonstrating that the pretreatment with LPS from P. agglomerans $(10 \mathrm{ng} / \mathrm{ml})$ or with monophosphoryl lipid A for $18 \mathrm{~h}$ was effective in the prevention of Alzheimer's disease by enhancing phagocytosis of $\beta$ amyloid by brain microglia [68]. Microglial cells were isolated from adult mouse brain.

Thus, the above results, indicating a high immunomodulatory activity of LPS, suggest their usage in the development of new drugs for various applications. However, therapeutic utilization of LPS is impeded by their high toxicity and pyrogenicity, as well as the insufficiency or inconstancy of their stimulating effect [69].

With regard to $P$. agglomerans, the LPS from the studied strains were characterized by a relatively low toxic effect ( $\mathrm{LD}_{50} 420$ and $147 \mu \mathrm{g} /$ mouse), in contrast to LPS from other Enterobacteriaceae family members ( $\mathrm{LD}_{50}$ range from 3.6 to $75 \mu \mathrm{g} /$ mouse) [70]; however they induce pyrogenic reactions [70].

Since lipid A is responsible for endotoxic activity, the researchers studied the role of fatty acids, in particular, their length and distribution on glucosamine molecules. It was found that lipids A with short-chain fatty acids were less toxic, or completely non-toxic compared to lipids A with long-chain fatty acids [14, 71, 72]. Hexaacyl bisphosphorylated lipid A structure with an asymmetric (4+2) distribution of acyl chains attached to diglucosamine was shown to be the most active, while its various modifications significantly affect the biological activity of LPS. Such hexaacyl bisphosphorylated lipid A is characterized by a large tilt angle, a conical (hexagonal) molecular shape and high endotoxic activity. Hexaacyl monophosphorylated lipid A has a smaller tilt angle, and the conical shape is less expressed tending to be more cylindrical (cubic) shape. This correlates with less pronounced endotoxic activity. Penta- and tetraacyl lipid A or hexaacyl lipid A with symmetric acyl chain distribution (3/3) are characterized by a small tilt angle, a cylindrical (lamellar) shape and are endotoxically inactive, but can be antagonistic (Table) [73].

Thus, it was shown that lipid A conformation plays a significant role in the manifestation of the LPS biological activity. Thus, so-called endotoxically active conformation corresponds to the cubic and hexagonal supramolecular structures, while the lamellar structure is endotoxically inactive.

Although lipid A was found to play the main role in the manifestation of the LPS biological activity, the length of the OPS, as well as the molecular mass of LPS, is also important [22, 74-76]. Thus, the literature described the LPS structure from one of the $P$. agglomerans strains, which contained at least two types of lipids A with different level of acylation. One of them is similar to $4^{\prime}$-monophosphorylhexaacyl lipid A from Escherichia coli, and the other - to 4'-monophosphorylheptaacyl lipid A from Salmonella enterica. These LPS also differed in molecular weight: low $5 \mathrm{kDa}$ and high 30$60 \mathrm{kDa}$, respectively. Hexaacyl lipid A was found to have high activity, including endogenous induction of TNF, while heptaacyl lipid A had lower activity. These LPS from P. agglomerans exhibited beneficial therapeutic effects, which were not observed for other LPS. It was suggested that these effects could not be attributed solely to the structure of lipid A. The length of the OPS chain and the LPS composition may also contribute greatly to the biological activity of lipid A.

Thus, Kohchi et al. [7] found that the OPS chain of IP-PA1 from P. agglomerans is shorter and characterized by a much lower molecular weight than the LPS of the type E. coli O:113 strain. Therefore, LPS IP-PA1 easily forms small-diameter mi- 
Chemical composition, molecular conformation and biological activity of different lipids A

\begin{tabular}{|c|c|c|c|c|}
\hline Conformation & $\begin{array}{l}\text { Supramolecular } \\
\text { structure }\end{array}$ & $\begin{array}{l}\text { Fatty acid } \\
\text { composition }\end{array}$ & Toxicity & Species of bacteria \\
\hline \multirow[b]{2}{*}{ r. } & \multirow[t]{2}{*}{ Lamellar } & $\begin{array}{r}3-\mathrm{OH}-\mathrm{C} 14: 0(2) \\
\text { 3-OH-C10:0 (2) } \\
\mathrm{C} 12: 1(1)\end{array}$ & \multirow[t]{2}{*}{ Not toxic } & Rhodobacter capsulatus \\
\hline & & $\begin{array}{l}\text { 3-OH-C14:0 (2) } \\
\text { 3-OH-C16:0 (2) }\end{array}$ & & Rhodospirillum fulvum \\
\hline & Cubic & $\begin{array}{r}3-\mathrm{OH}-\mathrm{C} 14: 0(2) \\
\mathrm{C} 12: 1(2)\end{array}$ & $\begin{array}{l}\text { Moderately } \\
\text { toxic }\end{array}$ & Escherichia coli \\
\hline & \multirow[b]{2}{*}{ Hexagonal } & 3-OH-C10:0 & \multirow[b]{2}{*}{ Hight toxic } & Rhodocyclus gelatinosus \\
\hline & & $\begin{array}{c}\text { 3-OH-C14:0 (2) } \\
\text { C12:0 } \\
\text { C16:0 }\end{array}$ & & Salmonella minnesota \\
\hline
\end{tabular}

celles, which can easily cross the mucous membrane and/or skin, enhancing positive effect of treatment after oral or subcutaneous administration.

Pupo et al. [77] demonstrated that LPS from E. coli containing short and long polysaccharide chains exhibited various biological activities on human macrophages. An essential role in the interaction of S-LPS with host cells is played by the LPS-binding protein. These results suggest that the polysaccharide part may affect the biological activity of LPS through serum factor.

Kadowaki et al. [78] divided the LPS IP-PA1 into two fractions: high-molecular (30-60 kDa) and low-molecular $(5 \mathrm{kDa})$. The first fraction contains long-chain OPS and the last one contains short oligosaccharides. These fractions induced different NO production in RAW264.7 cells.

The described results support the involvement of the LPS polysaccharide region in its biological effects.

Thus, the reported results $[59,62,63,78]$ indicated that the potential of biological activity of the LPS preparations from $P$. agglomerans was very similar to that of the LPS from most Enterobacteriaceae species (for example, Citrobacter freundii, Enterobacter aerogenes, Enterobacter cloacae, Klebsiella oxytoca, Salmonella typhi, Salmonella typhimurium) or Pseudomonadaceae (for example, Pseudomonas putida), and was higher compared to the LPS from other gram-negative bacteria, such as Agrobacterium sp. and Xanthomonas sinensis [62, 63] or Acinetobacter calcoaceticus and Alcaligenes fecalis [79].

The data found in literature and our own experimental results indicate the importance of the study of lipopolysaccharides of gram-negative bacteria, including $P$. agglomerans, a poorly-studied member of the Enterobacteriaceae family. Discovery of the heterogeneity of LPS, distinguished by unique structures of $\mathrm{O}$-specific polysaccharides, lipids A, characterized by different degrees of acylation, as well as serological activity and endotoxic properties not only contribute to the biological characteristics of the species but also could stimulate the development on their base of new drugs of various applications.

Further research focused on the clarification of the following aspects could be promising:

- the role of LPS in the pathogenesis of infectious diseases - this will contribute to the development of a new effective approach to combating diseases caused by gram-negative bacteria;

- the ability of modified lipopolysaccharides to modulate both the innate and adaptive immune response;

- the possibility of using synthetic polysaccharides as components of vaccines, adjuvants, anticancer drugs, nonspecific stimulants. 
Conflict of interest. Authors have completed the Unified Conflicts of Interest form at http:// ukrbiochemjournal.org/wp-content/uploads/2018/12/ coi_disclosure.pdf and declare no conflict of interest.

\section{ЛІПОПОЛІСАХАРИДИ Pantoea agglomerans: СТРУКТУРА, ФУНКЦІОНАЛЬНА ТА БІОЛОГІЧНА АКТИВНІСТЬ}

\section{Л. Д. Варбанечь, Т. В. Булигіна, \\ Л. А. Пасічник, Н. В. Житкевич}

\author{
Інститут мікробіології і вірусології \\ ім. Д. К. Заболотного НАН України, Київ; \\ e-mail: varbanets_imv@ukr.net
}

В огляді наведені дані літератури, а також результати власних експериментальних досліджень ліпополісахаридів (ЛПС) грамнегативних бактерій. Основну увагу автори приділяють Pantoea agglomerans, представнику родини Enterobacteriaceae. Вперше описано унікальні структури О-специфічних полісахаридних ланцюгів їхніх ліпополісахаридів, які можуть бути як розгалуженими, так і лінійними тетра- і пентасахаридними ланцюгами, що повторюються. Показана гетерогенність як самої молекули ЛПС, так і присутність в бактеріальній клітині декількох ЛПС, які відрізняються структурою ліпідів А, О-специфічних полісахаридних ланцюгів, серологічною активністю, а також ендотоксичними властивостями, зокрема токсичністю i пірогенністю. Така гетерогенність є одним із механізмів поліфункціональності ЛПС. На основі О-антигенності ЛПС вперше було проведено серотипування штамів $P$. agglomerans і віднесено ï до 10 серогруп. Висока імуномодулювальна активність ЛПС P. agglomerans дозволяє припустити використання їхніх олігосахаридних фрагментів для створення кон'югованих вакцин проти захворювань, спричинених грамнегативними бактеріями.

Кл ючові слов а: Pantoea agglomerans, О-специфічний полісахарид, ліпід А, серологічна активність, TLR 4 рецептор, біологічна активність.

\section{References}

1. Walterson AM, Stavrinides J. Pantoea: insights into a highly versatile and diverse genus within the Enterobacteriaceae. FEMS Microbiol Rev. 2015; 39(6): 968-984.

2. Gavini F, Mergaert J, Beji A, Mielcarek C, Izard D, Kersters K, De Ley J. Transfer of Enterobacter agglomerans (Beijerinck 1988) Ewing and File 1972 to Pantoea gen. nov. as Pantoe a agglomerans comb. nov. and deccription of Pantoea dispersa sp. nov. Int J Syst Bacteriol. 1989; 39(3): 337-345.

3. Quecine MC, Araújo WL, Rossetto PB, Ferreira A, Tsui S, Lacava PT, Mondin M, Azevedo JL, Pizzirani-Kleiner AA. Sugarcane growth promotion by the endophytic bacterium Pantoea agglomerans 33.1. Appl Environ Microbiol. 2012; 78(21): 7511-7518.

4. Völksch B, Thon S, Jacobsen ID, Gube M. Polyphasic study of plant- and clinicassociated Pantoea agglomerans strains reveals indistinguishable virulence potential. Infect Genet Evol. 2009; 9(6): 1381-1391.

5. Loncaric I, Heigl H, Licek E, Moosbeckhofer R, Busse H-J., Rosengarten R. Typing of Pantoea agglomerans isolated from colonies of honey bees (Apis mellifera) and culturability of selected strains from honey. Apidologie. 2009; 40(1): 4054.

6. Rylander R, Burrell R. Endotoxins in inhalation research. Summary of conclusions of a workshop held at Clearwater, Florida, USA, 28-30 September 1987. Ann Occup Hyg. 1988; 32(4): 553-556.

7. Kohchi C, Inagawa H, Nishizawa T, Yamaguchi T, Nagai S, Soma G. Applications of lipopolysaccharide derived from Pantoea agglomerans (IP-PA1) for health care based on macrophage network theory. $J$ Biosci Bioeng. 2006; 102(6): 485-496.

8. Nicoletti G, Corbella M, Jaber O, Marone P, Scevola D, Faga A. Non-pathogenic microflora of a spring water with regenerative properties. Biomed Rep. 2015; 3(6): 758-762.

9. Valiente Moro C, Tran FH, Raharimalala FN, Ravelonandro P, Mavingui P. Diversity of culturable bacteria including Pantoea in wild mosquito Aedes albopictus. BMC Microbiol. 2013; 13: 70. 
10. Bisi DC, Lampe DJ. Secretion of antiPlasmodium effector proteins from a natural Pantoea agglomerans isolate by using PelB and HlyA secretion signals. Appl Environ Microbiol. 2011; 77(13): 4669-4675.

11. Wang S, Ghosh AK, Bongio N, Stebbings KA, Lampe DJ, Jacobs-Lorena M. Fighting malaria with engineered symbiotic bacteria from vector mosquitoes. Proc Natl Acad Sci USA. 2012; 109(31): 12734-12739.

12. Dow M, Newman MA, von Roepenack E. The induction and modulation of plant defense responses by bacterial lipopolysaccharides. Annu Rev Phytopathol. 2000; 38: 241-261.

13. Nadarasah G, Stavrinides J. Quantitative evaluation of the host-colonizing capabilities of the enteric bacterium Pantoea using plant and insect hosts. Microbiology. 2014; 160(Pt 3): 602615.

14. Takeuchi O, Akira S. Pattern recognition receptors and inflammation. Cell. 2010; 140(6): 805-820.

15. Kim S, Patel DS, Park S, Slusky J, Klauda JB, Widmalm G, Im W. Bilayer Properties of lipid A from various gram-negative bacteria. Biophys $J$. 2016; 111(8): 1750-1760.

16. Raetz CR, Whitfield C. Lipopolysaccharide endotoxins. Annu Rev Biochem. 2002; 71: 635700.

17. Holst O, Molinaro A. Core oligosaccharide and lipid A components of lipopolysaccharides. In: Moran A, Brennan P, Holst O, von Itszstein M (eds.). Microbial glycobiology: structures relevance and applications. San Diego: Elsevier. 2009. P. 29-56.

18. Galanos C, Freudenberg MA. Bacterial endotoxins: biological properties and mechanisms of action. Mediators Inflamm. 1993; 2(7): S11-S16.

19. Homma JY, Matsuura M, Kanegasaki S, Kawakubo Y, Kojima Y, Shibukawa N, Kumazawa Y, Yamamoto A, Tanamoto K, Yasuda T, Imoto M, Yoshimura H, Kusumoto S, Shiba T. Structural requirements of lipid A responsible for the functions: a study with chemically synthesized lipid A and its analogues. J Biochem. 1985; 98(2): 395-406.

20. Kotani S, Takada H, Tsujimoto M, Ogawa T, Takahashi I, Ikeda T, Otsuka K, Shimauchi H, Kasai N, Mashimo J, et al. Synthetic lipid A with endotoxic and related biological activities comparable to those of a natural lipid A from an
Escherichia coli re-mutant. Infect Immun. 1985; 49(1): 225-237.

21. Varbanets LD, Brovarskaya OS, Bulygina TV, Garkavaya EG, Zhitkevich NV. Characterization of Pantoea agglomerans lipopolysaccharides. Microbiology. 2014; 83(6): 754-763.

22. Tsukioka D, Nishizawa T, Miyase T, Achiwa K, Suda T, Soma G, Mizuno D. Structural characterization of lipid A obtained from Pantoea agglomerans lipopolysaccharide. FEMS Microbiol Lett. 1997; 149(2): 239-244.

23. Mayer H, Krauss JH, Yokota A, Weckesser J. Natural variants of lipid A. Adv Exp Med Biol. 1990; 256: 45-70.

24. Moran AP, Lindner B, Walsh EJ. Structural characterization of the lipid A component of Helicobacter pylori rough- and smooth-form lipopolysaccharides. J Bacteriol. 1997; 179(20): 6453-6463.

25. Gitaitis RD, Gay JD. First report of a leaf blight, seed stalk rot, and bulb decay of onion by Pantoea ananas in Georgia. Plant Dis. 1997; 81(9): 1096.

26. Knirel YA, Valvano MA. Structure, chemical synthesis, biogenesis and interactions with host cells. Wien-N.Y.: Springer-Verlag, 2011. 433 p.

27. Trent MS, Ribeiro AA, Lin S, Cotter RJ, Raetz CR. An inner membrane enzyme in Salmonella and Escherichia coli that transfers 4-amino-4-deoxy-L-arabinose to lipid A: induction on polymyxin-resistant mutants and role of a novel lipid-linked donor. $J$ Biol Chem. 2001; 276(46): 43122-43131.

28. Zdorovenko EL, Kadykova AA, Shashkov AS, Varbanets LD, Bulyhina TV, Knirel YA. Lipopolysaccharide of Pantoea agglomerans 7969: Chemical identification, function and biological activity. Carbohydr Polym. 2017; 165: 351-358.

29. Zdorovenko EL, Kadykova AA, Shashkov AS, Varbanets LD, Bulyhina TV, Knirel YA. Lipopolysaccharides of Pantoea agglomerans 7604 and 8674 with structurally related O-polysaccharide chains: Chemical identification and biological properties. Carbohydr Polym. 2018; 181: 386-393.

30. Mattsby-Baltzer I, Mielniczuk Z, Larsson L, Lindgren K, Goodwin S. Lipid A in Helicobacter pylori. Infect Immun. 1992; 60(10): 4383-4387.

31. Leone S, Molinaro A, Pessione E, Mazzoli R, Giunta C, Sturiale L, Garozzo D, Lanzetta R, Parrilli M. Structural elucidation of the core- 
lipid A backbone from the lipopolysaccharide of Acinetobacter radioresistens S13, anorganic solvent tolerant Gram-negative bacterium. Carbohydr Res. 2006; 341(5): 582-590.

32. Raetz CR, Reynolds CM, Trent MS, Bishop RE. Lipid A modification systems in gram-negative bacteria. Annu Rev Biochem. 2007; 76(1): 295329.

33. Cole RB, Domelsmith LN, David CM, Laine RA, DeLucca AJ. ${ }^{252} \mathrm{Cf}$ plasma-desorption mass spectrometry of lipid A from Enterobacter agglomerans. Rapid Commun Mass Spectrom. 1992; 6(10): 616-622.

34. Karamanos Y, KolO, Wieruszeski JM, Strecker G, Fournet B, Zalisz R. Structure of the O-specific polysaccharide chain of the lipopolysaccharide of Enterobacter agglomerans. Carbohydr Res. 1992; 231: 197-204.

35. Bulyhina TV, Varbanets LD, Pasichnyk L A, Zhitkevych NV. Antibiotic resistance of Pantoea agglomerans. Microbiol Biotechnol. 2016; 1(33): 68-75. (In Ukrainian).

36. Varbanets LD, Zdorovenko GM, Knirel YuA. Methods of endotoxin investigations. K.: Naukova dumka, 2006. 238 p. (In Ukrainian).

37. Kabanov DS, Prokhorenko IR. Structural analysis of lipopolysaccharides from Gramnegative bacteria. Biochemistry (Mosc). 2010; 75(4): 383-404.

38. Cimmino A, Marchi G, Surico G, Hanuszkiewicz A, Evidente A, Holst O. The structure of the O-specific polysaccharide of the lipopolysaccharide from Pantoea agglomerans strain FL1. Carbohydr Res. 2008; 343(2): 392396.

39. Hashimoto M, Satou R, Ozono M, Inagawa $H$, Soma GI. Characterization of the O-antigen polysaccharide derived from Pantoea agglomerans IG1 lipopolysaccharide. Carbohydr Res. 2017; 449: 32-36.

40. Jansson PE, Kenne L, Wehler T. A 2D-1Hn.m.r. study of some Shigella flexneri O-polysaccharides. Carbohydr Res. 1987; 166(2): 271-282.

41. Holst O, Aucken HM, Seltmann G. Structural and serological characterization of the O-specific polysaccharide of the lipopolysaccharide from proposed new serotype O29 of Serratia marcescens. J Endotoxin Res. 1997; 4(3): 215220.
42. Kołodziejska K, Perepelov AV, Zabłotni A, Drzewiecka D, Senchenkova SN, Zych K, Shashkov AS, Knirel YA, Sidorczyk Z. Structure of the glycerol phosphate-containing O-polysaccharides and serological studies of the lipopolysaccharides of Proteus mirabilis CCUG 10704 (OE) and Proteus vulgaris TG 103 classified into a new Proteus serogroup, O54. FEMS Immunol Med Microbiol. 2006; 47(2): 267-274.

43. Winn AM, Wilkinson SG. Structure of the O6 antigen of Stenotrophomonas (Xanthomonas or Pseudomonas) maltophilia. Carbohydr Res. 1995; 272(2): 225-230.

44. Westphal O. Bacterial Endotoxins. Molecular and cellular aspects of allergy. Trans College Intern Allergol. 1975; 49: 1-43.

45. Zdorovenko EL, Varbanets LD, Liu B, Valueva OA, Wang Q, Shashkov AS, Garkavaya EG, Brovarskaya OS, Wang L, Knirel YA. Structure and gene cluster of the O antigen of Escherichia coli L-19, a candidate for a new O-serogroup. Microbiology. 2014; 160(Pt 9): 2102-2107.

46. Culbertson RJr, Osburn BI. The biologic effects of bacterial endotoxin: a short review. Vet Sci Commun. 1980; 4(1): 3-14.

47. Poltorak A, He X, Smirnova I, Liu MY, Van Huffel C, Du X, Birdwell D, Alejos E, Silva M, Galanos C, Freudenberg M, RicciardiCastagnoli P, Layton B, Beutler B. Defective LPS signaling in $\mathrm{C} 3 \mathrm{H} / \mathrm{HeJ}$ and $\mathrm{C} 57 \mathrm{BL} / 10 \mathrm{ScCr}$ mice: mutations in Tlr4 gene. Science. 1998; 282(5396): 2085-2088.

48. Volchenkov R, Sprater F, Vogelsang P, Appel S. The 2011 Nobel Prize in physiology or medicine. Scand J Immunol. 2012; 75(1): 2033-2040.

49. Piazza M, Yu L, Teghanemt A, Gioannini T, Weiss J, Peri F. Evidence of a specific interaction between new synthetic antisepsis agents and CD14. Biochemistry. 2009; 48(51): 12337-12344.

50. Shimazu R, Akashi S, Ogata H, Nagai Y, Fukudome K, Miyake K, Kimoto M. MD-2, a molecule that confers lipopolysaccharide responsiveness on Toll-like receptor 4. $J$ Exp Med. 1999; 189(11): 1777-1782.

51. Inohara N, Nuñez G. ML - a conserved domain involved in innate immunity and lipid metabolism. Trends Biochem Sci. 2002; 27(5): 219-221. 
52. Resman N, Vasl J, Oblak A, Pristovsek P, Gioannini TL, Weiss JP, Jerala R. Essential roles of hydrophobic residues in both MD-2 and tolllike receptor 4 in activation by endotoxin. $J$ Biol Chem. 2009; 284(22): 15052-15060.

53. Gangloff M, Gay NJ. MD-2: the Toll 'gatekeeper' in endotoxin signalling. Trends Biochem Sci. 2004; 29(6): 294-300.

54. Gruber A, Mancek M, Wagner H, Kirschning CJ, Jerala R. Structural model of MD-2 and functional role of its basic amino acid clusters involved in cellular lipopolysaccharide recognition. J Biol Chem. 2004; 279(27): 2847528482.

55. Ohto U, Fukase K, Miyake K, Satow Y. Crystal structures of human MD-2 and its complex with antiendotoxic lipid IVa. Science. 2007; 316(5831): 1632-1634.

56. Kim HM, Park BS, Kim JI, Kim SE, Lee J, Oh SC, Enkhbayar P, Matsushima N, Lee H, Yoo OJ, Lee JO. Crystal structure of the TLR4MD-2 complex with bound endotoxin antagonist Eritoran. Cell. 2007; 130(5): 906-917.

57. Dinarello CA. Interleukin-1 and interleukin-1 antagonism. Blood. 1991; 77(8): 1627-1652.

58. Medzhitov R, Janeway C Jr. Innate immunity. $N$ Engl J Med. 2000; 343(5): 338-344.

59. Dutkiewicz J. Studies on endotoxin of Erwinia herbicola and their biological activity. Zentralbl Bakteriol Orig A. 1976; 236(4): 487-508.

60. Thomas L. The role of epinephrine in the reactions produced by the endotoxins of gram-negative bacteria. I. Hemorrhagic necrosis produced by epinephrine in the skin of endotoxin-treated rabbits. J Exp Med. 1956; 104(6): 865-880.

61. Rylander R, Lundholm M. Bacterial contamination of cotton and cotton dust and effects on the lung. Br J Ind Med. 1978; 35(3): 204-207.

62. Helander I, Salkinoja-Salonen M, Rylander R. Chemical structure and inhalation toxicity of lipopolysaccharides from bacteria on cotton. Infect Immun. 1980; 29(3): 859-862.

63. Helander I, Saxén H, Salkinoja-Salonen M, Rylander R. Pulmonary toxicity of endotoxins: comparison of lipopolysaccharides from various bacterial species. Infect Immun. 1982; 35(2): 528-532.

64. Inagawa $H$, Nishizawa $T$, Takagi $K$, Goto $S$, Soma G, Mizuno D. Antitumor mechanism of intradermal administration of lipopolysaccharide. Anticancer Res. 1997; 17(3C): 1961-1964.

65. Iwamoto I, Goto S, Kera J, Soma G, Takeuchi S, Nagata Y. Mechanistic analysis of high antitumor effect of intradermal administration of lipopolysaccharide from Pantoea agglomerans. Med Oncol. 1996; 13(2): 103-109.

66. Inagawa H, Nishizawa T, Noguchi K, Minamimura M, Takagi K, Goto S, Soma G, Mizuno D. Anti-tumor effect of lipopolysaccharide by intradermal administration as a novel drug delivery system. Anticancer Res. 1997; 17(3C): 2153-2158.

67. Dutkiewicz J, Mackiewicz B, Lemieszek MK, Golec M, Skórska C, Góra-Florek A, Milanowski J. Pantoea agglomerans: a mysterious bacterium of evil and good. Part II Deleterious effects: Dust-borne endotoxins and allergens - focus on grain dust, other agricultural dusts and wood dust. Ann Agric Environ Med. 2016; 23(1): 6-29.

68. Kobayashi Y, Inagawa H, Kohchi C, Okazaki K, Zhang R, Soma G. Effect of lipopolysaccharide derived from Pantoea agglomerans on the phagocytic activity of amyloid $\beta$ by primary murine microglial cells. Anticancer Res. 2016; 36(7): 3693-3698.

69. Brady CL, Venter SN, Cleenwerck I, Engelbeen K, de Vos P, Wingfield MJ, Telechea N, Coutinho TA. Isolation of Enterobacter cowanii from Eucalyptus showing symptoms of bacterial blight and dieback in Uruguay. Lett Appl Microbiol. 2009; 49(4): 461-465.

70. Shubshinskyi VV, Varbanets LD, Brovarskaya OS. Endotoxic activity of Pragia fontium lipopolysaccharides. Modern Toxicol Probl. 2007; 4: 35-38. (In Ukrainian).

71. Silipo A, De Castro C, Lanzetta R, Parrilli M, Molinaro A. Lipopolysaccharides. In: Konig H, Claus H, Varma A (eds.). Prokaryotic cell wall compounds - structure and biochemistry. Heidelberg: Springer. 2010. P. 133-154.

72. Holst O, Molinaro A. Microbial glycobiology: structures relevance and applications. San Diego: Elsevier. 2009. 1020 p.

73. Seydel U, Oikawa M, Fukase K, Kusumoto S, Brandenburg K. Intrinsic conformation of lipid A is responsible for agonistic and antagonistic activity. Eur J Biochem. 2000; 267(10): 30323039. 
74. Kadowaki T, Inagawa H, Kohchi C, Hirashima M, Soma G. Functional characterization of lipopolysaccharide derived from symbiotic bacteria in rice as a macrophage-activating substance. Anticancer Res. 2011; 31(7): 24672476.

75. Shimada M, Kadowaki T, Taniguchi Y, Inagawa $\mathrm{H}$, Okazaki $\mathrm{K}$, Soma $\mathrm{G}$. The involvement of O-antigen polysaccharide in lipopolysaccharide in macrophage activation. Anticancer Res. 2012; 32(6):2337-2341.

76. Kadowaki T, Ohno S, Taniguchi Y, Inagawa H, Kohchi C, Soma G. Induction of nitric oxide production in RAW264.7 cells under serumfree conditions by O-antigen polysaccharide of lipopolysaccharide. Anticancer Res. 2013; 33(7): 2875-2879.

77. Pupo E, Lindner B, Brade H, Schromm AB. Intact rough- and smooth-form lipopolysaccharides from Escherichia coli separated by preparative gel electrophoresis exhibit differential biologic activity in human macrophages. FEBS J. 2013; 280(4): 1095-1111.

78. Salkinoja-Salonen M., Helander I., Rylander R. Toxic bacterial dusts associated with plants. In: Rhodes-Roberts M, Skinner FA (eds.). Bacteria and Plants. Soc Appl Bact Symp Ser. No. 10. London: Academic Press; 1982. p. 219-233.

79. Dutkiewicz J, Skórska C, Sitkowska J, Ochalska B, Kaczmarski F. Properties of the endotoxins produced by various gram-negative bacteria present in occupational environments. In: Jacobs RR, Wakelyn PJ, Rylander R, Burrell R. (eds.). Cotton Dust. Proceedings of the $12^{\text {th }}$ Cotton Dust Research Conference and of the Endotoxin Inhalation Workshop, 28-30 September 1987, Clearwater: FL; 1988. p. 187189. 